\title{
RANCANG BANGUN REAKTOR BIOGAS TIPE PORTABLE DARI LIMBAH KOTORAN TERNAK SAPI
}

\author{
Design of Portable Biogas Reactor Type for Cow Dung Waste
}

\section{Guyup Mahardhian Dwi Putra ${ }^{1, *)}$, Sirajuddin Haji Abdullah ${ }^{1}$, Asih Priyati ${ }^{1}$, Diah Ajeng Setiawati $^{1}$, Surya Abdul Muttalib ${ }^{1}$}

\author{
${ }^{1}$ Program Studi Teknik Pertanian Fakultas Teknologi Pangan dan Agroindustri \\ Universitas Mataram \\ Email $^{*)}$ :guyupmdp@gmail.com
}

Diterima: 12 Desember 2016

Disetujui: 1 Februari 2017

\begin{abstract}
The aim of this study were 1) Designing small-scale portable biogas reactors, 2) analyze the quality of biogas flame test regard to the temperature, $\mathrm{pH}$, and pressure. The method used in this study is an experimental method to measure the parameters of biogas reactor, i.e. temperature, pressure, acidity $(\mathrm{pH})$ and the volume of produced gas. This study used materials of cow dung and water at ratio of 1:2 in a capacity of 200 liters. Data were collected for 37 days. Results from this study is a laboratory scale floating type biodisgeter made of plastic and fiber glass, with a diameter of $52 \mathrm{~cm}$ and $92 \mathrm{~cm}$ high. The volume of biogas produced during 37 days was $2.721 \mathrm{~m}^{3}$ with average formation gas of $0.074 \mathrm{~m}^{3} /$ day and the combustion rate of 66.44 liters/hour.
\end{abstract}

Keywords: biogas, cow manure, combustion time, volume

\begin{abstract}
ABSTRAK
Tujuan dari penelitian ini adalah (1) merancang reaktor biogas skala kecil dan portable dan (2) menganalis kualitas uji nyala api biogas dengan memperhatikan suhu, $\mathrm{pH}$, dan tekanan. Metode yang digunakan pada penelitian ini adalah metode eksperimental dengan mengukur parameter suhu reaktor biogas, tekanan, derajat keasaman $(\mathrm{pH})$ dan volume gas yang dihasilkan. Penelitian ini menggunakan bahan kotoran sapi dan air dengan perbandingan 1:2 pada kapasitas 200 liter. Pengambilan data dilakukan selama 37 hari. Hasil dari penelitian ini adalah sebuah alat biodigester skala laboratorium tipe floating drum atau terapung yang terbuat dari bahan plastik dan fiber glass dengan diamater reaktor $52 \mathrm{~cm}$ dan tinggi $92 \mathrm{~cm}$. Volume biogas yang dihasilkan selama 37 hari adalah $2,721 \mathrm{~m}^{3}$ dengan ata-rata pembentukan gas sebesar $0,074 \mathrm{~m}^{3} /$ hari dan laju pembakaran 66,44 liter/jam.
\end{abstract}

Kata kunci: biogas, kotoran sapi, lama pembakaran, volume

\section{PENDAHULUAN}

Kenaikan harga minyak dunia sangat berpengaruh terhadap kehidupan masyarakat Indonesia, terutama masyarakat kecil. Harga minyak dunia yang mahal memaksa pemerintah untuk menaikkan harga bahan bakar minyak. Subsidi pemerintah akan dialokasikan pada bidang lain seperti pendidikan dan kesehatan. Mungkin akan lebih baik jika sebagian dana subsidi BBM tersebut digunakan untuk pengembangan sumber energi alternatif.

Dari data BPS tahun 2013 mengenai tingkat pertumbuhan ternak di kawasan Nusa Tenggara Barat, terlihat bahwa pertumbuhan sapi dari tahun ke tahun semakin meningkat dengan tingkat pertumbuhan rata-rata per tahun 14,09. Peningkatan jumlah sapi tentu saja akan berimbas pada peningkatan limbah kotoran yang dihasilkan. Seekor sapi dengan 
berat $454 \mathrm{~kg}$ akan menghasilkan $30 \mathrm{~kg}$ limbah feses dan urine setiap hari. Kita bisa membayangkan jika memelihara 100 ekor sapi, jumlah limbah yang dihasilkan 3 ton per hari.

Dengan instalasi biogas, peternak akan mendapatkan gas sebagai bahan bakar serta pupuk organik padat dan cair dari sisa fermentasi bahan organik dalam digester biogas. Selain itu, dapat mengurangi pencemaran akibat tumpukan feses. Instalasi biogas dapat dibuat dalam skala rumah tangga maupun skala besar. Saat ini ketika harga bahan bakar minyak melambung tinggi, pemanfaatan kotoran sebagai bahan baku penghasil biogas bisa menjadi alternatif yang tepat.

Dari uraian tersebut maka perlu dilakukan penelitian mengenai kajian pemanfaatan limbah ternak sebagai bahan baku pembuatan biogas. Adapun tujuan penelitian ini adalah (1) merancang reaktor biogas skala kecil dan portable dan (2) menganalis kualitas uji nyala api biogas dengan memperhatikan suhu, $\mathrm{pH}$, dan tekanan.

\section{METODOLOGI PENELITIAN}

\section{Waktu dan tempat penelitian}

Penelitian dilaksanakan dari bulan Mei 2016 sampai dengan Desember 2016 bertempat di Laboratorium Daya dan Mesin Pertanian Fakultas Teknologi Pangan dan Agroindustri Universitas Mataram.

\section{Bahan dan Alat Penelitian}

Bahan penelitian: kotoran sapi yang telah dibersihkan dari rumput ataupun batu. Sebelum di masukkan kedalam biodigester kotoran sapi yang telah bersih dicampur air dengan perbandingan 1:2.

Alat penelitian: bor listrik, termokopel $\mathrm{CA}$ tipe $\mathrm{CC}$, timbangan digital, timbangan analitis, rekam data YokoGawa Model FX 106 - 1-2, pipa PVC 0,5 inchi, dan kran 0,5 inchi.

\section{Parameter Desain dan Pengukuran}

\section{Analisis Desain Rancangan Struktural dan Fungsional}

Analisis desain diperlukan untuk menghitung kebutuhan limbah kotoran ternak dan kapasitas maksimal yang dapat dicapai pada alat biodigester. Selain itu juga dijelaskan fungsi dari bagian-bagian biodigester.

\section{Performansi alat}

Pengamatan performansi dari alat penghasil biogas model terapung ini dilakukan dengan cara melihat kinerja alat mulai dari memasukkan bahan hingga alat dapat diaplikasikan ke kompor biogas.

\section{Tekanan biogas}

Pengukuran tekanan biogas dilakukan dengan melihat angka atau nilai yang ditunjukkan oleh manometer $U$ yang diukur tiap hari pada tangki. Besamya nilai tekanan yang ditunjukkan oleh manometer $\mathrm{U}$ menunjukkan besarnya tekanan dan produksi biogas yang dihasilkan.

\section{Volume biogas $\left(\mathbf{m}^{3}\right)$}

Pengukuran volume gas yang dihasilkan dilakukan dengan melihat perubahan ketinggian tangki pengumpul.

$V=\pi r^{2} \cdot t(1)$

Dimana :

$\mathrm{V}=$ volume biogas $\left(\mathrm{m}^{3}\right)$

$\mathrm{r}=$ jari-jari drum penampung $(\mathrm{m})$

$\mathrm{t}=$ selisih tinggi drum penampung $(\mathrm{m})$

\section{Lama nyala api (menit)}

Lama nyala api dihitung dengan melihat lamanya waktu yang terpakai pada kompor gas mulai dari api menyala hingga api mati.

\section{Massa jenis $(\rho)\left(\mathrm{kg} / \mathrm{m}^{3}\right)$}

Satuan SI massa jenis adalah $\mathrm{kg} / \mathrm{m}^{3}$. Suatu zat berapapun massanya dan berapapun volumenya akan memiliki massa jenis yang sama. Rumus untuk menentukan massa jenis adalah:

$\rho=\frac{m}{v}$

Dimana:

$\mathrm{P} \quad=$ massa jenis $\left(\mathrm{kg} / \mathrm{m}^{3}\right.$ atau $\left.\mathrm{g} / \mathrm{cm}^{3}\right)$

$\mathrm{m} \quad=$ massa $(\mathrm{kg}$ atau $\mathrm{g})$

$\mathrm{v} \quad=$ volume $\left(\mathrm{m}^{3}\right.$ atau $\left.\mathrm{cm}^{3}\right)$ 


\section{Laju pembakaran (liter/menit)}

Laju pembakaran bahan bakar campuran merupakan kecepatan bahan bakar habis pada tangki minyak pada uji bakar menggunakan kompor tekan sistem injeksi langsung. Laju pembakaran dapat dihitung menggunakan persamaan di bawah ini :

Laju pembakaran $=$

Volume Bahan Bakar (liter)

waktu sampai bahan bakar habis(menit)

\section{Rancangan Desain}

Gambar 1 menunjukkan rancangan desain biodigester yang dilakukan dalam penelitian ini.

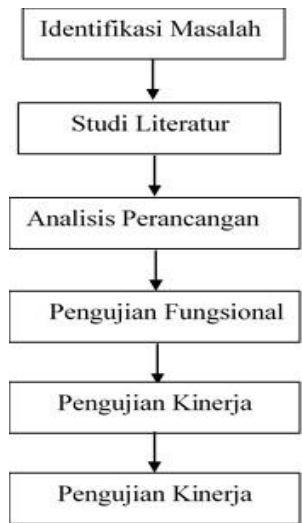

Gambar 1. Rancangan Desain

Adapun prosedur penelitian dapat dilihat pada

Gambar 2.

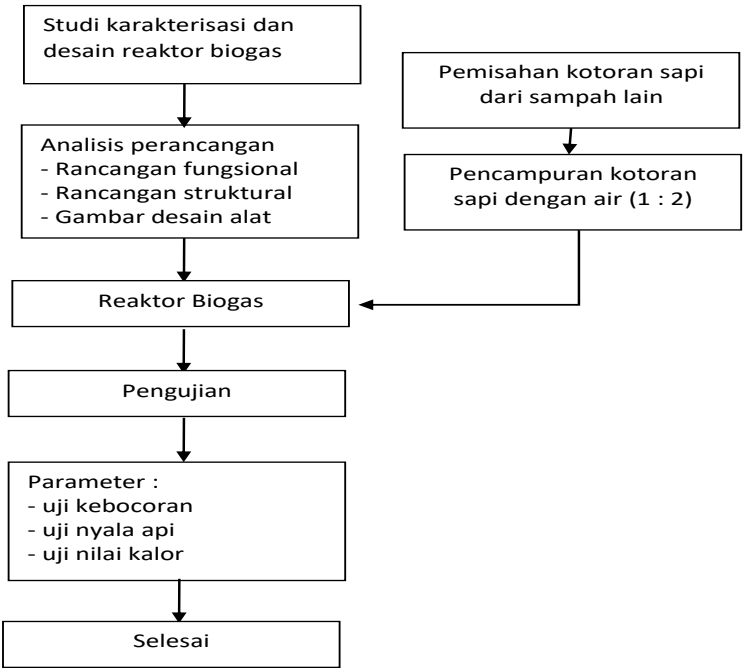

Gambar 2. Prosedur Penelitian

\section{HASIL DAN PEMBAHASAN}

Analisis Desain Rancangan Struktural

\section{Perhitungan volume digester}

$$
\begin{aligned}
\mathrm{V} & =\pi \mathrm{r}^{2} \times \mathrm{t} \\
& =3,14 \times(26)^{2} \times 92 \\
& =195.282,88 \mathrm{~cm}^{3} \\
& =0,19 \mathrm{~m}^{3} \\
& =195,28 \text { liter } \approx 200 \text { liter }
\end{aligned}
$$

\section{Banyaknya kotoran sapi yang dibutuhkan}

Dalam perhitungan untuk menentukan jumlah kotoran sapi yang dibutuhkan untuk menghasilkan biogas yang akan digunakan. Terlebih dahulu dihitung massa jenis kotoran sapi dengan menggunakan persamaan 2:

Diketahui massa kotoran sapi ditimbang seberat $1,46 \mathrm{~kg}$ dengan menggunakan ember dengan volume $0,00108 \mathrm{~m}^{3}$.

Sehingga massa jenis kotoran sapi adalah $1351,85 \mathrm{~kg} / \mathrm{m}^{3}$.

a. Volume digester $=0,19 \mathrm{~m}^{3}$ atau 200 liter

b. Volume (V) bubur kotoran adalah 3/4 dari volume digester dengan perbandingan air dan kotoran sapi, yaitu $2: 1$

$$
\begin{aligned}
V & =\frac{3}{4} x 0,19 \mathrm{~m}^{3} \\
& =0,1425 \mathrm{~m}^{3} \text { volume digester } \\
& \text { yang diisi bubur kotoran sapi. }
\end{aligned}
$$

Jadi dalam digester diperlukan 0,107 $\mathrm{m}^{3}$ air dan $0,036 \mathrm{~m}^{3}$ kotoran sapi

c. Massa kotoran sapi $\left(\mathrm{M}_{\mathrm{s}}\right)$ yang dibutuhkan:

$$
\begin{aligned}
\mathrm{M}_{\mathrm{s}} & =1351,85 \mathrm{~kg} / \mathrm{m}^{3} \times 0,036 \mathrm{~m}^{3} \\
& =48,67 \mathrm{~kg}
\end{aligned}
$$

d. Massa air $\left(\mathrm{M}_{\mathrm{a}}\right)$ yang dibutuhkan:

$$
\begin{aligned}
\mathrm{M}_{\mathrm{a}} & =1000 \mathrm{~kg} / \mathrm{m}^{3} \times 0,107 \mathrm{~m}^{3} \\
& =107 \mathrm{~kg}
\end{aligned}
$$

\section{Manomater}

Manometer adalah alat ukur untuk mengukur tekanan. Manometer dibuat dengan prinsip pipa $U$ dengan fluida air yang diberi zat warna untuk mengetahui tekanan biogas yang dihasilkan selama proses berlangsung dalam satuan atm. Bila manometer diberi tekanan gas dalam salah satu kolom, maka air di kolom lainnya akan naik hingga mencapai tekanan tertentu. Perbedaan ketinggian ini di kedua kolom dinyatakan dengan nilai (h). 
4. Tekanan dihitung dengan menggunakan Hukum Boyle seperti rumus di bawah (Rohyami, 2012):

$$
\mathbf{P}=\text { o.g.h + tekanan atmosfer }
$$

Keterangan :

$\mathrm{P}=$ Tekanan absolut $\left(\mathrm{N} / \mathrm{m}^{2}\right)$

$\rho=$ Densitas zat cair $(\mathrm{kg} / \mathrm{m} 3)=1000 \mathrm{~kg} / \mathrm{m}^{3}$

$\mathrm{g}=$ Percepatan gravitasi $\left(9,81 \mathrm{~m} / \mathrm{s}^{2}\right)$

$\mathrm{h}=$ Perbedaan ketinggian kolom zat cair yang digunakan $(\mathrm{m})$

$1 \mathrm{~atm}=101.325 \mathrm{~N} / \mathrm{m}^{2}$

$1 \mathrm{~N} / \mathrm{m}^{2}=9,869 \times 10^{-6} \mathrm{~atm}$

\section{Analisis Desain Rancangan Fungsional}

Jenis reaktor yang digunakan dalam penelitian ini adalah reaktor floating drum. Keuntungan dari reaktor ini adalah dapat melihat secara langsung volume gas yang tersimpan pada drum karena pergerakannya. Karena tempat penyimpanan yang terapung sehingga tekanan gas konstan. Reaktor ini terdiri dari bebepa bagian diantaranya (1) digester yang digunakan sebagai tempat pencerna material biogas dan sebagai rumah bagi bakteri, baik bakteri pembentuk asam ataupun bakteri pembentuk gas metana, (2) penampung gas yang dapat bergerak menggunakan peralatan sejenis drum. Drum ini dapat bergerak naik turun yang berfungsi untuk menyimpan gas hasil fermentasi dalam digester. Drum akan bergerak naik atau mengapung pada cairan ketika ada gas yang memenuhi ruang penampung gas, semakin banyak gas yang dihasilkan semakin tinggi penampung gas akan terapung, (3) lubang inlet yang berfungsi sebagai tempat pemasukan bahan limbah kotoran ternak (4) lubang outlet sebagai tempat pengeluaran limbah yang telah selesai digunakan.

Jenis bahan yang digunakan untuk pembuatan reaktor ini adalah fiber plastik. Bahan fiber memiliki kelebihan diantaranya kuat, tahan lama, tidak berkarat, anti bocor serta ringan.

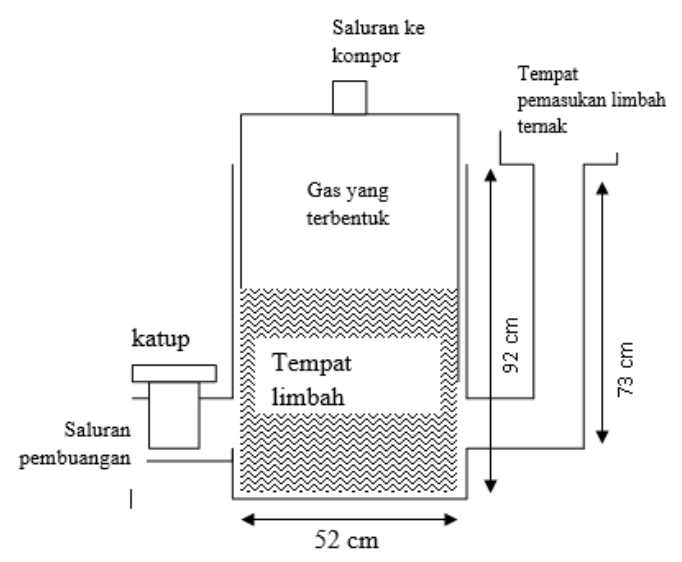

Gambar 3. Rancangan desain reaktor floating drum

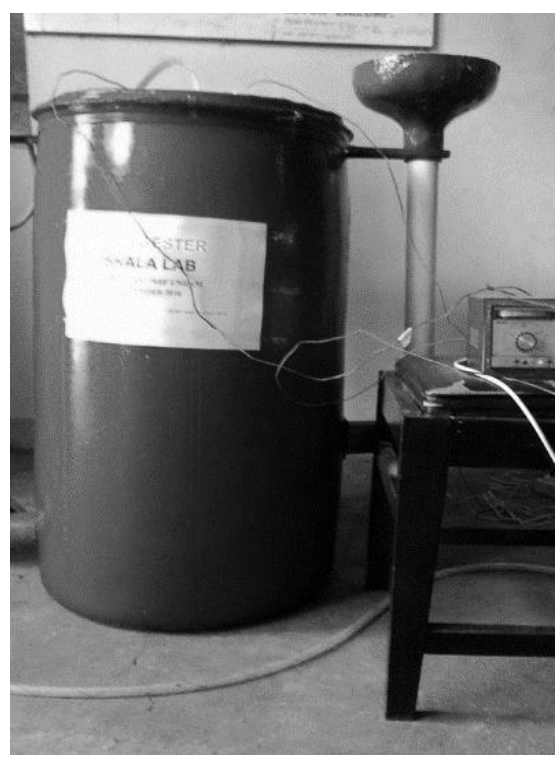

Gambar 4. Reaktor biogas hasil rancangan

\section{Temperatur biodigester}

Temperatur yang tinggi umumnya akan memberikan produksi biogas yang baik. Namun suhu tersebut sebaiknya tidak boleh melebihi suhu kamar. Bakteri ini hanya dapat berkembang bila suhu disekitarnya berada pada suhu kamar. Suhu yang baik untuk proses pembentukan biogas berkisar antara $20-40^{\circ} \mathrm{C}$ dan suhu optimum antara $28-30^{\circ} \mathrm{C}$. Temperatur selama proses berlangsung sangat penting karena hal ini berkaitan dengan kemampuan hidup bakteri pemroses biogas, yaitu berkisar $27^{\circ} \mathrm{C}-28^{\circ} \mathrm{C}$. Dengan temperatur itu, proses pembuatan biogas akan berjalan sesuai dengan waktunya. Tetapi berbeda bila temperatur terlalu rendah (dingin), maka waktu untuk membentuk biogas akan lebih lama (Paimin, 2000). Dari hasil penelitian diperoleh temperatur dalam biodigester cenderung stabil 
dengan rata-rata suhu $31,15^{\circ} \mathrm{C}$ dengan suhu maksimal $32,11^{\circ} \mathrm{C}$ dan suhu minimum $29,49^{\circ} \mathrm{C}$. Suhu lingkungan diperoleh berkisar $30,59^{\circ} \mathrm{C}$ dengan suhu maksimal $32^{\circ} \mathrm{C}$ dan suhu minimum $26^{\circ} \mathrm{C}$.

\section{Tekanan biogas}

Tekanan biogas selama fermentasi cenderung mengalami perubahan yaitu mengalami kenaikan dan penurunan. Dari grafik dibawah ini dapat dilihat perubahan tekanan selama fermentasi.

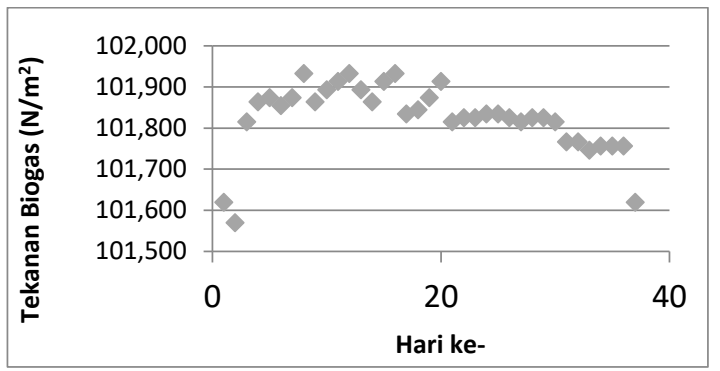

Gambar 5. Tekanan Biogas

Gambar 5 memperlihatkan hubungan tekanan yang dihasilkan oleh biogas dengan waktu. Pada hari ke-1 sudah tampak adanya kenaikan tekanan sebesar 101,619 N/ $\mathrm{m}^{2}$. Semakin bertambahnya hari, tekanan dalam biogas terus bertambah. Tekanan biogas yang semakin besar mengindikasikan bahwa biogas yang dihasilkan juga semakin banyak (Insani, 2013) dan tekanan maksimal tercapai pada hari ke 16 yaitu $101,933 \mathrm{~N} / \mathrm{m}^{2}$. Hal ini sesuai dengan pernyataan Hadi (1981) yang menyatakan bahwa peningkatan penambahan waktu fermentasi dari 10 hari hingga 30 hari meningkatkan produksi biogas sebesar 50\%. Hasil penelitian ini menunjukkan terjadi penurunan tekanan pada hari ke 20 sampai hari ke 37. Hal ini disebabkan karena proses degradasi anaerob dalam biogas sudah semakin berkurang. Tekanan yang dihasilkan oleh biogas ini sudah mampu digunakan untuk menyalakan api dalam kompor gas.

\section{PH}

Kisaran $\mathrm{pH}$ optimal untuk produksi methan adalah 7,0 sampai 7,2 , tetapi pada kisaran 6.8 sampai 8.0 masih diperbolehkan (Sitorus, 2011). Nilai pH dalam penelitian ini rata-rata 6,94 sehingga nilai $\mathrm{pH}$ dalam reaktor biogas dapat dikatakan cukup baik untuk produksi gas metan.
Dalam bioreaktor, terdapat dua bakteri yang berperan, yaitu bakteri asam dan bakteri metan. Kedua jenis bakteri ini harus eksis dalam jumlah yang berimbang. Kegagalan proses pembuatan biogas dapat dikarenakan oleh tidak seimbangnya populasi bakteri metan terhadap bakteri asam yang menyebabkan lingkungan menjadi sangat asam ( $\mathrm{pH}$ kurang dari 7) yang selanjutnya menghambat kelangsungan hidup bakteri metan. Keasaman substrat yang dianjurkan berada pada rentang pH 6.5 sampai 8 (Sitorus, 2011).

\section{Volume Biogas}

Perubahan volume dalam biogas dapat dilihat pada Gambar 6. Dimana volume maksimal biogas bernilai $0,101 \mathrm{~m}^{3}$. Volume maksimal ini didapatkan dengan menggunakan rumus ketinggian maksimum pada drum penampung gas dikalikan dengan diameter drum penampung.

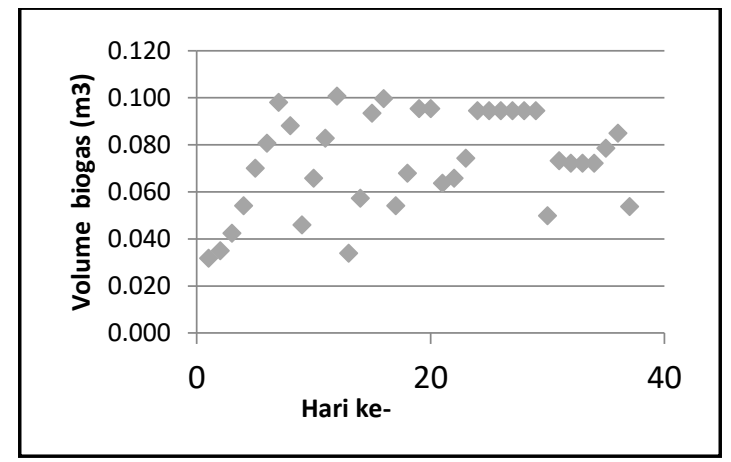

Gambar 6. Volume Biogas

Dari Gambar 6, terlihat perubahan volume biogas sangat fluktuatif. Hal ini disebabkan pada saat drum telah mencapai ketinggian maksimum, gas harus dibuang untuk menampung kembali gas yang akan terbentuk. Sama halnya dengan tekanan dimana pada hari ke 20 mulai terjadi penurunan volume sampai pada hari ke 37. Artinya bahwa gas yang tebentuk dalam drum penampung sudah semakin berkurang. Jumlah biogas yang terbentuk dapat dihitung dengan akumulasi terbentuknya gas dari hari pertama sampai terakhir, sehingga didapatkan jumlah gas yang terbentuk sebesar $2,721 \mathrm{~m}^{3}$ atau ratarata pembentukan gas sebesar $0,074 \mathrm{~m}^{3} /$ hari.

\section{Lama Nyala Api}

Lama nyala api diperoleh dari pengujian api pada kompor biogas. Pengujian dilakukan pada saat volume tangki penampung 
gas mencapai maksimum yaitu $0,101 \mathrm{~m}^{3}$. Nyala api dalam penelitian ini diuji coba menggunakan nyala api besar dan nyala api kecil. Pada nyala api besar didapatkan hasil, dimana untuk memanaskan 750 gr air sampai gas dalam drum penampung habis, dibutuhkan waktu 7 menit, dengan sisa massa air sebesar 675 gr dengan suhu $73^{\circ} \mathrm{C}$.

Dari hasil uji nyoba nyala api besar ternyata waktu yang diperlukan untuk memanaskan air sangat singkat, sehingga percobaan selanjutnya dilakukan dengan menggunakan nyala api kecil. Dari hasil uji coba nyala api kecil waktu total yang dapat digunakan untuk memanaskan air adalah 181 menit dengan suhu akhir tata-rata $91,5^{\circ} \mathrm{C}$. Selain itu warna nyala api besar masih campuran warna biru dan kuning, hal ini disebabkan pada awal pembakaran masih banyak kandungan gas selain metana. Sedangkan pada nyala api kecil warnanya sudah cenderung biru merata, hal ini karena gas metana sudah sudah homogen.

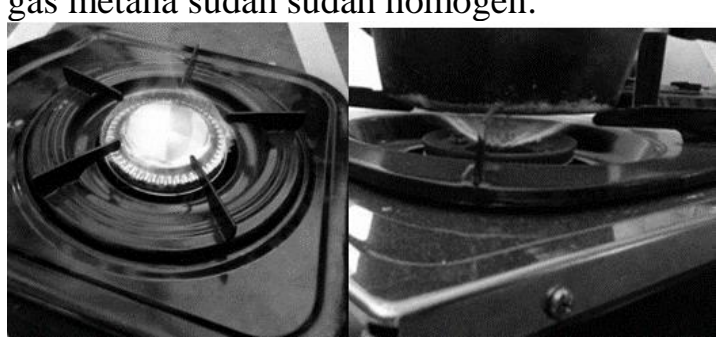

(a)

(b)

Gambar 7. (a) nyala api besar, (b) nyala api kecil

Jika dibandingkan dengan hasil penelitian Amaru (2006) yang menyatakan bahwa biodigester dengan kapasitas penyimpan gas $2,5 \mathrm{~m}^{3}$ dapat dimanfaatkan untuk tungku pemasak selama 4-5 jam. Pada penelitian ini dengan menggunakan $0,19 \mathrm{~m}^{3}$ biodigester tipe floating drum dapat menghasilkan nyala api 181 menit atau 3,01 jam, sehingga sudah sangat baik.

\section{KESIMPULAN}

1. Dari hasil rancangan diperoleh dimensi biodigester dengan tinggi $92 \mathrm{~cm}$ dan jari jari $26 \mathrm{~cm}$, menghasilkan kapasitas sebesar
200 liter campuran kotoran sapi dengan air.

2. Tekanan yang dihasilkan biogas selama 37 hari adalah 101,84 N/m² dengan tekanan tertinggi 101,619 pada hari ke 16 dan tekanan terendah $101,756 \mathrm{~N} / \mathrm{m}^{2}$ pada hari ke 28.

3. Volume biogas yang dihasilkan selama 37 hari adalah $2,721 \mathrm{~m}^{3}$ dengan rata-rata pembentukan gas sebesar $0,074 \mathrm{~m}^{3} / \mathrm{hari}$.

4. Waktu total hasil pembakaran yang dapat digunakan untuk memanaskan air adalah 181 menit dengan suhu akhir tata-rata $91,5^{\circ} \mathrm{C}$.

\section{DAFTAR PUSTAKA}

Amaru, K., Michael A., Dian Y. S., Indah K., 2006. Teknologi Digester Gas Bio Skala Rumah Tangga. http://infoinfoanyar.blogspot.com/200 7/08/biogas.html [9 Januari 2008].

BPS. 2013. Nusa Tenggara Barat Dalam Angka (tahun) 2013. Mataram.

Hadi, N.1981. Gas Bio Sebagai Bahan Bakar. Lemigas, Cepu.

Insani, Metri Dian. 2013. Degradasi Anaerob Sampah Organik dengan Bioaktivator Effective Microorganism-5 (EM-5) untuk Menghasilkan Biogas. Jurnal Pendidikan Sains, Volume 1, Nomor 3, September 2013, Halaman 298-306.

Paimin. 2000. Alat Pembuat Biogas dari Batubata. Jakarta: Penebar Swadaya, Cetakan ke-3.

Rohyami. 2012. Hukum Gas ideal, http://rohyami.staff.uii.ac.id/2012/05/0 7/gas/, diakses 1 juli 2014

Sitorus. 2011. Pemanfaatan Lumpur Selokan sebagai Bahan Baku Biogas dengan Metode Batch Feeding. Skripsi. Jurusan Teknik Pertanian, Fakultas Teknologi Pertanian, Universitas Sumatera Utara, Medan. 